\title{
BORON FOLIAR APPLICATION ON SUNFLOWER (Helianthus annuus L.) ASSOCIATED WITH HERBICIDES
}

\author{
Brighenti, A.M. , Castro, C.
}

Embrapa Soja, Rodovia Carlos João Strass/Orlando Amaral, PO Box 231, Londrina, Paraná State, Brazil

Received: April 10, 2007 Accepted: February 23, 2008

\section{SUMMARY}

The present work was undertaken to evaluate volunteer corn control through the application of graminicides singly or combined with boron (B) sources as well as to assess the sunflower (Helianthus annuus L.) response to the application of this micronutrient. Experiments were arranged in a split-plot design with randomized complete blocks and five replications. The treatments applied were haloxyfop-methyl $0.048 \mathrm{~kg}$ a.i. $\mathrm{ha}^{-1}$ plus $0.5 \%(\mathrm{v} / \mathrm{v})$ mineral oil, sethoxydim $0.22 \mathrm{~kg}$ a.i. ha ${ }^{-1}$ plus $0.5 \%$ (v/v) mineral oil, clethodim $0.12 \mathrm{~kg}$ a.i. $\mathrm{ha}^{-1}$ plus $0.5 \%(\mathrm{v} / \mathrm{v})$ mineral oil, fluazifop-p-butyl $0.187 \mathrm{~kg}$ a.i. ha ${ }^{-1}$ and the hand-hoed control. The sub-plots consisted of the absence or presence of $400 \mathrm{~g}$ $\mathrm{ha}^{-1}$ of $\mathrm{B}$ from two sources $\left(\mathrm{H}_{3} \mathrm{BO}_{3}\right.$-boric acid and $\mathrm{Na}_{2} \mathrm{~B}_{8} \mathrm{O}_{13} \cdot 4 \mathrm{H}_{2} \mathrm{O}$-sodium borate), applied with the herbicides. All herbicides applied singly or combined with the two B sources were selective for the sunflower crop and efficient in controlling volunteer corn. The application of B in association with herbicides increased the content of this micronutrient in sunflower leaves.

Key words: plant nutrition, weed management, Zea mays, volunteer corn

\section{INTRODUCTION}

Sunflower (Helianthus annuus L.) requires greater quantities of B to satisfy its metabolic needs than other cultivated species.

The contents of B in Brazilian soils are generally low and the lack of this micronutrient has led to the occurrence of deficiency symptoms, mainly at flowering and maturity (Castro, 1999). Sunflower B deficiency symptoms range from death of roots and seedlings (Gil Martinez, 1995; Blamey et al., 1997) to wrinkled and deformed leaves, that become hard and bronze in color, and malformations of the head. Stem rupture and head dropping can also occur under B stress conditions.

* Corresponding author: Phone: 55 - 433371 6277; Fax: 55 - 4333716100 ; e-mail: brighent@cnpso.embrapa.br 
Yield reduction due to B deficiency is frequent, even if typical visual symptoms on leaves and heads are not evident (Castro, 1999). The reproductive stage of sunflower is more sensitive to low B supply in the soil than the vegetative stage (Asad et al., 2002).

Correction and prevention of B deficiency can be done through soil and foliar applications (Calle-Manzano, 1985; Shorrocks, 1997). The application of B, using fertilizers containing small pellets of this micronutrient, presents a disadvantage of segregating $B$ from the other components of the fertilizer during mixing and handling. This segregation interferes with the uniformity of B application to soils, due to the low quantities of the micronutrient that have to be applied (Mortvedt and Woodruff, 1993). Foliar fertilization is also used (Diggs et al., 1992; Asad et al., 2003). This practice increases production costs, soil compaction and plant breakage as a consequence of increased transit of machinery in the cropping area. Additionally, the low mobility of $B$ in the phloem may require several applications of the product to provide part of the $\mathrm{B}$ needed for new tissues, reproductive organs and achenes.

Another important factor that interferes with sunflower yield is the presence of volunteer plants emerging during the crop cycle. In Central Brazil, sunflower is generally cultivated after corn. Thus, volunteer plants can emerge during the sunflower cycle and cause considerable yield losses if present at high densities (Brighenti et al., 2003; Brighenti et al., 2005).

Simultaneous weed control and B supply to the crop, in a single operation, may be a feasible method of reducing sunflower production costs. Hence, the present work was undertaken to evaluate volunteer corn control through the application of graminicides singly or combined with B sources as well as the sunflower response to the application of this micronutrient.

\section{MATERIALS AND METHODS}

Two experiments were performed as parts of this study: one in Chapadão do Céu ( $18^{\circ} 23^{\prime} 34^{\prime \prime} \mathrm{S}$ and $52^{\circ} 39^{\prime} 57^{\prime}$ "W), Goiás State (experiment 1), and another in Chapadão do Sul ( $18^{\circ} 47^{\prime} 39^{\prime \prime} \mathrm{S}$ and $52^{\circ} 37^{\prime} 22^{\prime}$ W), Mato Grosso do Sul State (experiment 2), Brazil.

The experiments were arranged in a split-plot design with randomized complete blocks and five replications. The herbicides applied were haloxyfop-methyl $0.048 \mathrm{~kg}$ a.i. ha ${ }^{-1}$ plus $0.5 \%(\mathrm{v} / \mathrm{v})$ mineral oil, sethoxydim $0.22 \mathrm{~kg}$ a.i. ha ${ }^{-1}$ plus $0.5 \%$ (v/v) mineral oil, clethodim $0.12 \mathrm{~kg}$ a.i. $\mathrm{ha}^{-1}$ plus $0.5 \%(\mathrm{v} / \mathrm{v})$ mineral oil and fluazifop-p-butyl $0.187 \mathrm{~kg}$ a.i. ha ${ }^{-1}$. There was also a hand-hoed control. The sub-plots consisted of the absence or presence of $400 \mathrm{~g} \mathrm{ha}^{-1}$ of $\mathrm{B}$ from two sources $\left[\mathrm{H}_{3} \mathrm{BO}_{3}-\right.$ boric acid (17\% B) and $\mathrm{Na}_{2} \mathrm{~B}_{8} \mathrm{O}_{13} \cdot 4 \mathrm{H}_{2} \mathrm{O}$ - sodium borate $\left.(20.5 \% \mathrm{~B})\right]$.

Both experiments were sown in a Rhodic Hapludox soil, under no-tillage conditions, with $0.8 \mathrm{~m}$ inter-row spacing and five seeds per linear meter. After thinning, 
an average of 3.5 plants per linear meter was maintained, corresponding to a density of 43,750 plants $\mathrm{ha}^{-1}$.

The fertilization at sowing time was made with $300 \mathrm{~kg} \mathrm{ha}^{-1}$ of a 5-20-20 (NPK) formulation. Sidedressing was performed with $40 \mathrm{~kg} \mathrm{~N}^{-1} 30$ days after sowing.

Experiment 1 was sown on February 15, 2003. The sunflower hybrid Morgan 734 was used. Total sub-plot area was $28.0 \mathrm{~m}^{2}(4.0 \times 7.0 \mathrm{~m})$, and the net area, 14.4 $\mathrm{m}^{2}(2.4 \times 6.0 \mathrm{~m})$. Herbicides were applied on March 15, 2003, 25 days after sunflower emergence. Experiment 2 was sown on March 5, 2004, using the hybrid Helio 251. Total sub-plot area was $32.0 \mathrm{~m}^{2}(4.0 \times 8.0 \mathrm{~m})$, and the net area, $16.8 \mathrm{~m}^{2}$ $(2,4 \times 7.0 \mathrm{~m})$. Herbicides were applied on April 4, 2004, 27 days after sunflower emergence.

In both experiments, all treatments were applied using a $\mathrm{CO}_{2}$-pressurized backpack sprayer, calibrated to deliver $240 \mathrm{l} \mathrm{ha}^{-1}$ at $276 \mathrm{kPa}$, using flat-fan nozzles. During application, the volunteer corn plants had 4 to 5 leaves at a density of 12 plants $\mathrm{m}^{-2}$ (experiment 1 ) and 10 plants $\mathrm{m}^{-2}$ (experiment 2).

Visual crop injury and volunteer corn control ratings were obtained 17 and 31 days after application (DAA) (experiment 1) and 25 DAA (experiment 2). The ratings were made on a scale from 0 (no crop injury or no volunteer corn control) to $100 \%$ (crop death or total control of volunteer corn). Means values of plant height and sunflower stem diameter were obtained by randomly measuring ten plants within the net area of each sub-plot. The weight of a thousand achenes was obtained. The third or fourth leaf from the apex of ten plants was collected at the beginning of the flowering stage $\left(R_{5}\right)$ for $B$ content analysis. The leaves were washed with mild detergent and distilled water to remove any external B. Dry ashing was used for sample decomposition (Nogueira et al., 1998). At the same time, soil samples were collected from each sub-plot in experiment $2(0-10 \mathrm{~cm}$ soil layer) for B content determination using hot water extraction method (Nogueira et al., 1998).

Data were submitted to ANOVA and the means were compared by the Tukey test, at $5 \%$ probability.

\section{RESULTS AND DISCUSSION}

There was no evident injury caused by the treatments in experiment 1 after 17 DAA (Table 1). At 31 DAA, however, a slight leaf injury (chlorosis) was observed with values ranging from $0.4 \%$ to $1.4 \%$. These ratings of crop injury are acceptable and these injuries did not negatively affect sunflower yield. In experiment 2 (Table 2), no visual symptoms of crop injury were observed.

All treatments applied singly or in association with the two B sources were efficient in eliminating volunteer corn, with $100 \%$ control at the first evaluation date (experiment 1; Table 1). In experiment 2, percentages varied from $95 \%$ to $100 \%$ 


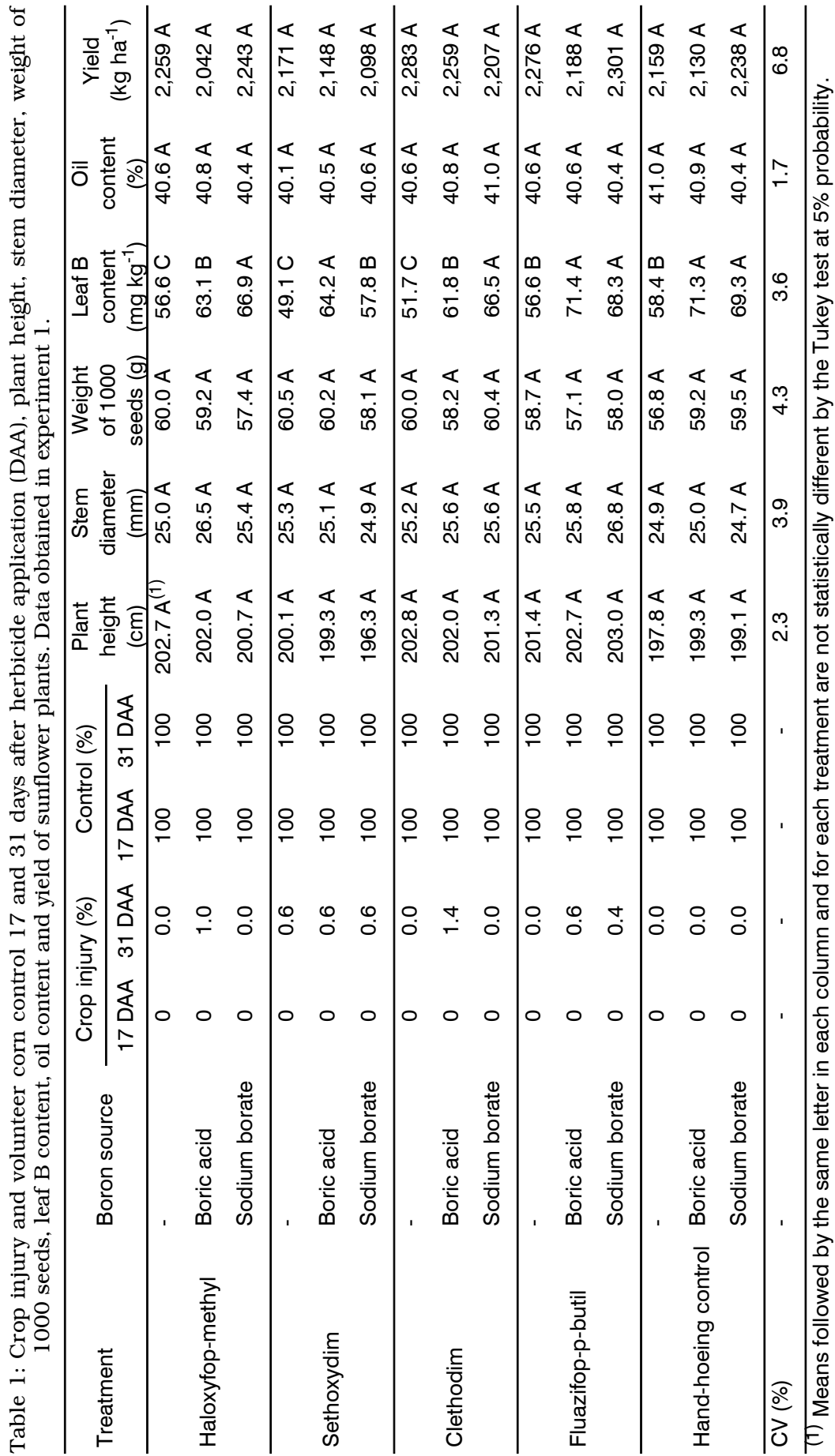




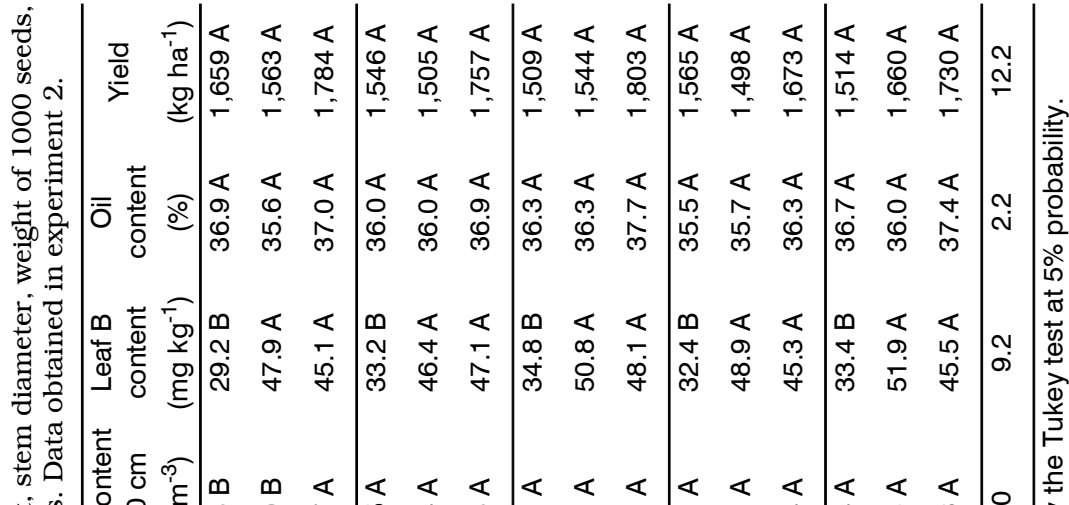
点离

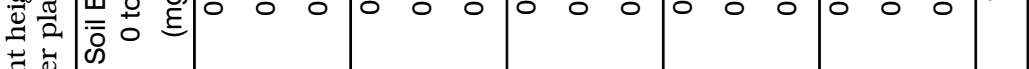

疍总

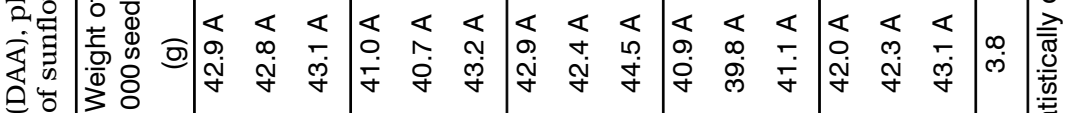

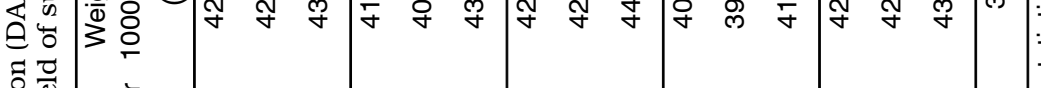
苞䓠

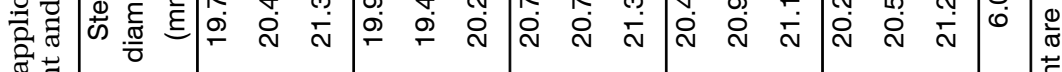
窇苞 急 券

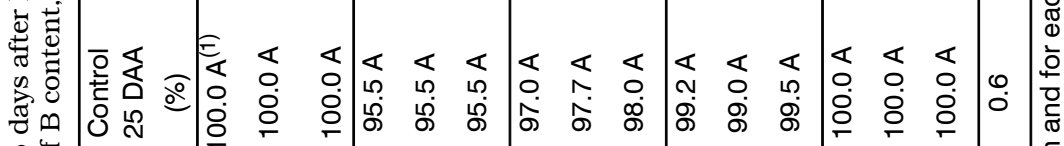

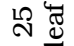

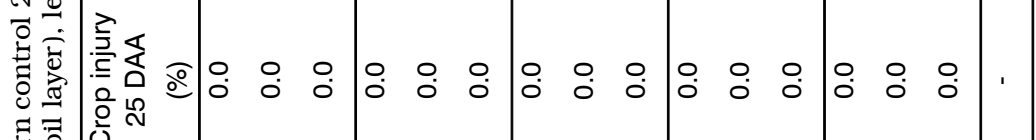

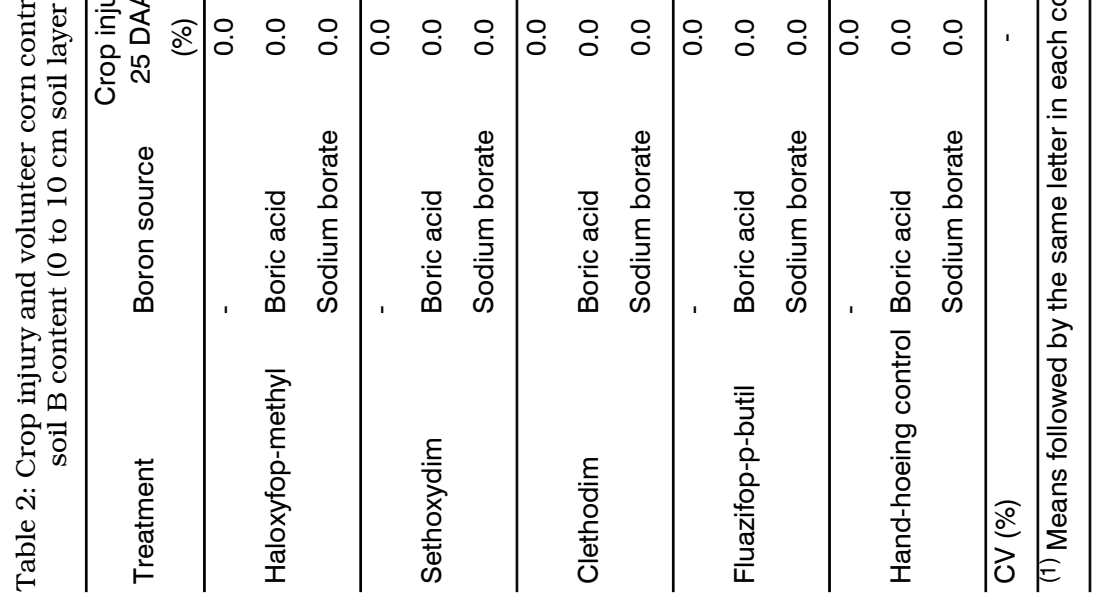


(Table 2), with no significant differences between the application of herbicides singly or in combination with the B sources.

In the treatment where the herbicides were applied singly, the mean B content in sunflower leaves was $54.5 \mathrm{mg} \mathrm{kg}^{-1}$ (experiment 1; Table 1). In tank mixtures of graminicides with the two B sources, a significant increase in leaf B content was observed in relation to the application of herbicides in isolation. Mean values were $66.4 \mathrm{mg} \mathrm{kg}^{-1}$ and $65.8 \mathrm{mg} \mathrm{kg}^{-1}$ in the treatments where the graminicides were associated with boric acid and sodium borate, respectively.

In experiment 2 , when the herbicides were applied singly, the mean B content in sunflower leaves was $32.6 \mathrm{mg} \mathrm{kg}^{-1}$, a value close to that established by Blamey et al. (1979) as critical (34 $\mathrm{mg} \mathrm{kg}^{-1}$ ). With the application of the graminicides and the B sources, there was an increase in B content in sunflower leaves. In the treatments where the herbicides were applied together with boric acid and sodium borate, B content in the leaves was $49.2 \mathrm{mg} \mathrm{kg}^{-1}$ and $46.2 \mathrm{mg} \mathrm{kg}^{-1}$, respectively. These values were greater than those obtained when the herbicides were applied without B. Castro et al. (2005) reported on the considerable increases in B content in sunflower leaves with foliar B application at rates of $0.3,0.5$, and $0.7 \mathrm{~kg} \mathrm{~B} \mathrm{ha}^{-1}, 40$ days after crop emergence. However, the two highest doses caused sunflower leaf burn.

In relation to $\mathrm{B}$ content in the soil, no significant differences were observed between the application of herbicides singly or in association with the two $\mathrm{B}$ sources, except for haloxyfop-methyl plus sodium borate (experiment 2 - Table 2). The amount of B applied was small, the increase being difficult to detect in the laboratory analysis. These amounts are classified as low for most crops. However, the $B$ increase in the soil was significant since the sunflower plants absorbed the B promptly, increasing B concentration in sunflower leaves.

Generally, boron deficiency symptoms are observed in new tissues, indicating that this nutrient is immobile in the phloem (Epstein and Bloom, 2005). However, plants that produce sugar alcohols such as sorbitol, manitol and dulcitol are exceptions. These compounds complex with $\mathrm{B}$, making it mobile in the phloem (Brown and $\mathrm{Hu}, 1996$; Brown and Shelp, 1997; Hu et al., 1997). This occurs in apple, nectarine and almond trees (Brown and $\mathrm{Hu}, 1996$ ), as well as in tobacco (Bellaloui et al., 1999). In prune trees, Hanson and Breen (1985) observed that Solubor application in the autumn, before leaf fall, resulted in greater fruit yield, indicating significant B translocation from senescent stems or leaves to reproductive parts. Brown and Shelp (1997) noticed that in species with high sorbitol content in the phloem, marked boron $\left({ }^{10} \mathrm{~B}\right)$ applied on the leaves moved from the treated leaves to the fruits in 15 days. In species with low sorbitol content, this movement did not take place, even when the concentrations applied were increased from $200 \%$ to $500 \%$. Other studies have also suggested that B may be translocated in the phloem; of particular note is the study of acquisition of B by peanuts (Arachis hypogaea) and subterranean clover (Trifolium subterraneum), when buried in a B-deficient white siliceous sand (Campbell et al., 1975). These species readily translocated B-polyol 
complexes in their phloem sap. Sunflower may translocate B from older to younger plant parts. However, further studies are needed to establish whether or not polyols are present in the phloem sap of sunflower and to determine whether B sprayed onto the stem, leaves or buds is responsible for the improved B status and growth of plant parts that developed after B sprays were applied (Asad et al., 2003).

Hence, considering the significant increase in B content of sunflower plants when they received the application of herbicides plus B sources, two arguments may be considered.

1. Boron increase in the leaves could be due only to available B in the soil, absorbed by the roots. In this case, $400 \mathrm{~g} \mathrm{~B} \mathrm{ha}^{-1}$ is considered a small amount and difficult to be detected by the laboratory method (hot water). The soil area covered by the sunflower plants did not surpass $50 \% 25$ to 30 days after plant emergence, when it is still possible to carry out mechanized pulverization in the field. Hence, the main target of the application was the soil. Therefore, the plant nutrition effect, mainly in the young developing parts may be due to the nutrient added to the soil and absorbed by the roots rather than to re-mobilization of the $B$ accumulated in mature tissues.

2. Boron increase in the leaves could be due to the increase in soil, which was absorbed by roots, plus that applied to the leaves, that could have been transported in the phloem from the applied leaves to the younger plant parts.

Considering sunflower plant height, stem diameter, weight of 1000 seeds, oil content and yield, there were no significant differences among the treatments (Table 1 and Table 2). Boaretto et al. (1997) observed that the non-correlation among the increases in B content in the leaves and yield can be explained by the difficulty in removing this micronutrient retained in the foliar cuticle or that connected to the pectic layer of the cell wall. Castro et al. (2005) also reported lack of yield responses to the application of $0.3,0.5$ and $0.7 \mathrm{~kg} \mathrm{ha}^{-1}$ doses of B. However, low B supply in the soil can lead to drastic yield reduction. Finally, it is possible that sunflower yield could be limited by factors other than B availability.

\section{CONCLUSIONS}

All herbicides applied singly or combined with the two B sources $\left(\mathrm{H}_{3} \mathrm{BO}_{3}-\right.$ boric acid and $\mathrm{Na}_{2} \mathrm{~B}_{8} \mathrm{O}_{13} \cdot 4 \mathrm{H}_{2} \mathrm{O}$ - sodium borate) were selective for the sunflower crop and efficient in controlling volunteer corn. The application of $\mathrm{B}$ in association with herbicides increased the content of this micronutrient in sunflower leaves.

\section{ACKNOWLEDGEMENTS}

We thank Reinaldo T. Moriyama, José Zucca Morais, Rubson Sibaltelly and Roberval Fagundes for assistance in collecting data for our 
research and George G. Brown and José Francisco Ferraz de Toledo for valuable suggestions in completing the manuscript.

\section{REFERENCES}

Asad, A., Blamey, F.P.C. and Edwards, D.G., 2002. Dry matter production and boron concentrations of vegetative and reproductive tissues of canola and sunflower plants grown in nutrient solution. Plant and Soil 243: 243-252.

Asad, A., Blamey, F.P.C. and Edwards, D.G., 2003. Effects of boron foliar application on vegetative and reproductive growth of sunflower. Annals of Botany 92: 565-570.

Bellaloui, N., Brown, P.H. and Dandekar, A.M., 1999. Manipulation of in vitro sorbitol production alters boron uptake and transport in tobacco. Plant Physiology 119: 735-742.

Blamey, F.P.C., Mould, D. and Chapman, J., 1979. Critical boron concentrations in plant tissue of two sunflower cultivars. Agronomy Journal 71: 243-247.

Blamey, F.P.C., Zollinger, R.K. and Schneiter, A.A., 1997. Sunflower production and culture. In: Schneiter A.A., (ed.) Sunflower Technology and Production. American Society of Agronomy: Madison, 595-670.

Boaretto, A.E., Tiritan, C.S. and Muraoka, T., 1997. Effects of foliar applications of boron on citrus fruit and on foliage and soil boron concentration. In: Bell, R.W. and Rerkasem, B. (eds.) Boron in Soils and Plants. Kluwer Academic Publishers, 121-123.

Brighenti, A.M., Castro, C., Gazziero, D.L.P., Adegas, F.S. and Voll, E., 2003. Cadastramento fitossociológico de plantas daninhas na cultura do girassol. Pesquisa Agropecuária Brasileira 38: 651-657.

Brighenti, A.M., Castro, C., Gazziero, D.L.P. and Voll, E., 2005. Manejo de plantas daninhas no girassol. In: Leite, R.M.V.B.C., Brighenti, A.M. and Castro, C. eds. Girassol no Brasil. Londrina: Embrapa Soja, 411-469.

Brown, P.H. and Hu, H., 1996. Phloem mobility of boron in species dependent: evidence for phloem mobility in sorbitol-rich species. Annals of Botany 77: 497-505.

Brown, P.H. and Shelp, B.J., 1997. Boron mobility in plants. Plant and Soil 193: 85-101.

Campbell, L.C., Miller, M.H. and Loneragan, J.F., 1975. Translocation of boron to plant fruits. Australian Journal of Plant Physiology 2: 481-487.

Castro, C., 1999. Boro e estresse hídrico na nutrição e produção do girassol em casa-devegetação. DS Tese, Escola Superior de Agricultura Luiz de Queiroz, Piracicaba, Brazil.

Castro, C., Oliveira, F.A., Salinet, L. and Veronesi, C.O., 2005. Aplicação de ácido bórico via foliar na cultura do girassol. XVI Reunião Nacional de Pesquisa de Girassol (Londrina, Brazil, 4-6 October 2005), 123-125.

Calle-Manzano, C.L. de la, 1985. Carencia de boro en girasol. Hojas divulgadoras 7, 1-12.

Diggs, C.A., Ratto de Miguez, M.S. and Shorrocks, V.M., 1992. Boron deficiency symptoms evaluation: the most accurate method to decide sunflower boron fertilization. Proceedings of the $13^{\text {th }}$ International Sunflower Conference (Pisa, Italy, 8-10 September 1992), 1-7.

Epstein, E. and Bloom, A.J., 2005. Mineral nutrition of plants; principles and perspectives. 2nd ed. Sunderland: Sinauer Associates, 400.

Gil Martinez, F., 1995. Elementos de fisiología vegetal: relaciones hídricas, nutrición mineral, transporte, metabolismo. Madrid: Ediciones Mundi-Prensa, 249-283.

Hanson, E.J. and Breen, P.J., 1985. Effects of fall boron sprays and environmental factors on fruit set and boron accumulation in "Italian" prune flowers. Journal of American Society for Horticultural Science 110: 389-392.

Hu, H., Penn, S.G., Lebrilla, C.B. and Brown, P.H., 1997. Isolation and characterization of soluble boron complexes in higher plants. The mechanism of phloem mobility of boron. Plant Physiology 113: 649-655.

Mortvedt, J.J. and Woodruff, J.R., 1993. Technology and application of boron fertilizers for crops. In: Gupta, U.C., (ed.) Boron and Its Role in Crop Production. CRC Press: Boca Raton, 157-176.

Nogueira, A.R.A., Machado, P.L.O.A., Carmo, C.A.F.S. and Ferreira, J.R., 1998. Manual de laboratórios: solo, água, nutrição vegetal, nutrição animal e alimentos. EMBRAPACPPSE, São Carlos, pp. 1-72.

Shorrocks, V.M., 1997. The occurrence and correction of boron deficiency. Plant and Soil 193: 121-148. 


\title{
APLICACIÓN FOLIAR DE BORO EN GIRASOL (Helianthus annuus L.) ASOCIADA A HERBICIDAS
}

\author{
RESUMEN
}

El presente trabajo ha sido conducido con el fin de evaluar el control de plantas voluntarias de maíz por medio de la aplicación de herbicidas de gramíneas aislada y combinada con fuentes de boro (B), así como la respuesta del girasol (Helianthus annuus) a la aplicación de ese micro nutriente. El delineamiento experimental ha sido en bloques casualizados en parcelas subdivididas, con cinco repeticiones. Los tratamientos aplicados en las parcelas han sido haloxyfop-methyl $0,048 \mathrm{~kg}$ i.a. ha ${ }^{-1}$ más $0,5 \%(\mathrm{v} / \mathrm{v})$ de aceite mineral, sethoxydim $0,22 \mathrm{~kg}$ i.a. ha ${ }^{-1}$ más $0,5 \%(\mathrm{v} / \mathrm{v})$ de aceite mineral, clethodim 0,12 $\mathrm{kg}$ i.a. ha ${ }^{-1}$ más $0,5 \%(\mathrm{v} / \mathrm{v})$ de aceite mineral, fluazifop-p-butyl $0,187 \mathrm{~kg}$ i.a. ha 1 y el testigo segado. Las subparcelas consistieron de la ausencia o de la presencia de $400 \mathrm{~g} \mathrm{ha}^{-1}$ de $\mathrm{B}$ en dos fuentes $\left(\mathrm{H}_{3} \mathrm{BO}_{3}\right.$ - ácido bórico y $\mathrm{Na}_{2} \mathrm{~B}_{8} \mathrm{O}_{13} \cdot 4 \mathrm{H}_{2} \mathrm{O}$ - borato de sodio), aplicados juntamente con los herbicidas de gramíneas. Todos los herbicidas aplicados aisladamente o combinados con las fuentes de B han sido selectivos para el girasol y eficientes en el control de las plantas voluntarias de maíz. La aplicación de boro en asociación con los herbicidas de gramíneas aumentó el contenido de ese micro nutriente en las hojas de girasol.

\section{APPLICATION FOLIAR DE BORE SUR LÊ TOURNESOL (Helianthus annuus) ASSOCIÉ AUX HERBICIDES}

\author{
RÉSUMÉ
}

Le présent travail a été mené afin d'évaluer le contrôle de plantes volontaires de mais, et ceci au moyen de l'application d'herbicides, isolée et combinée avec des sources de bore (B), et également afin d'évaluer la réaction du tournesol (Helianthus annuus) à l'application de cette micronutrition. Les traitements appliqués sur les parcelles étaient haloxyfop-methyl 0,048 kg i.a. $\mathrm{ha}^{-1}$ plus $0,5 \%(\mathrm{v} / \mathrm{v})$ d'huile minérale, sethoxydim $0,22 \mathrm{~kg}^{2}$ i.a. ha ${ }^{-1}$ plus $0,5 \%(\mathrm{v} /$ v) d'huile minerale, clethodim $0,12 \mathrm{~kg}$ i.a. $\mathrm{ha}^{-1}$ plus $0,5 \%(\mathrm{v} / \mathrm{v})$ d'huile minerale, fluazifop-p-butyl 0,187 kg i.a. ha ${ }^{-1}$ et un test (pour désherber les plantes volontaires de mais). Les subparcelles résidaient en l'absence ou la présence de 400 $\mathrm{g} \mathrm{ha}^{-1}$ de $\mathrm{B}$ em deux origines $\left(\mathrm{H}_{3} \mathrm{BO}_{3}\right.$ - acide borique et $\mathrm{Na}_{2} \mathrm{~B}_{8} \mathrm{O}_{13} \cdot 4 \mathrm{H}_{2} \mathrm{O}-$ borate de sodium), appliqués conjointement avec les herbicides. Tous les herbicides appliqués isolément ou em combinaison avec les sources de B se sont avérés sélectifs pour le tournesol et efficaces dans le contrôle des plantes volontaires de mais. L'application de bore en association avec les herbicides a augmenté le contenu de bore sur les feuilles de tournesol. 
